\title{
The Dynamic Nature of Competitive Advantage of the Firm
}

\author{
Lilla Hortovanyi ${ }^{\mathrm{i}}$ \\ Strategic Management Department, Corvinus University of Budapest, Hungary
}

Copyright $(2016$ by authors, all rights reserved. Authors agree that this article remains permanently open access under the terms of the Creative Commons Attribution License 4.0 International License

\begin{abstract}
Trade through tougher competition expels less efficient forms from the market. As Rita G. McGrath [1] put it forward, in today's business environment the competitive advantage often evaporates in less than a year. While this seems to be devastating, in fact this is an opportunity for new comers. Twenty-five leading companies across various sectors were analyzed in-depth, drawing on more than 100 interviews with managers and knowledge workers. The study found that dynamic comparative advantage is the ultimate source of sustainable competitive advantage and investment into both high productivity and high absorptive capacity is required.
\end{abstract}

Keywords Competitive Advantage, Comparative Advantage, Absorptive Capacity, Productivity, Organizational Learning, Competitive Dynamics

\section{Introduction}

\subsection{Theory of Comparative Advantage}

In his 1817 book, On the Principles of Political Economy and Taxation, David Ricardo[2] defined comparative advantage as the benefit gained by nations from specializing in those activities in which they have the greatest advantages or least disadvantages over other nations. After specialization and trade, both nations can increase their welfare even if one has an absolute advantage in both activities. A nation has a comparative advantage over another if it can produce a good or a service at a lower opportunity cost.

Recent developments in thinking have been triggered by new ways of thinking about firm heterogeneity. The major theoretical break-through is associated with the works of Melitz[3], Helpman, Melitz and Yeaple[4] and others that induced the increasing use of micro-level datasets in a large number of countries to study firm level heterogeneity. For example, Greenway and Kneller[5] examined the link between productivity and exposure to foreign markets, and concluded that firm heterogeneity can be explained by differences in productivity, self-selection, and learning.

Productivity gains are vital to the long-term performance of a company as they mean that more is being accomplished with less. Capital and labor are both scarce resources, so maximizing their impact is a core concern of all businesses. Johansson[6] and many others suggest that productivity differences driven by technology factors give rise to traditional Ricardian comparative advantages and specialization along the product quality range. Taking it one step further, my view is that firms should specialize in those activities in which they have a comparative advantage relative to their buyers or suppliers. Although comparative advantage is calculated in relation to a particular buyer, competitive offerings can still be compared, creating a hierarchy: the highest value reflects the best offering for the buyer.

The more competitive the environment is, more pressure on the firms to increase their market knowledge, which further stimulates learning mechanisms, productivity as well as innovation capability. Not surprisingly, firms with a customer-centric structure - an organizational design that aligns each business unit with a distinct customer group - are often found to realize superior performance compared to firms that are internally structured. Over the past decade many companies therefore refocused their structures on customer segments rather than products - about $30 \%$ of Fortune 500 firms including Intel, IBM, and American Express [8]. That trend also suggests a fresh look at firm level comparative advantage.

\subsection{Competitive and Comparative Advantage}

Competitive advantage is considered as an absolute advantage, and it exists when the offering of a firm stands out from the competition because of its superior value or unique benefits to buyers. This can include quality, features, prices, location, service, and delivery, as well as customer relations and even brand personality. As a consequence, there will be 
either more buyers are willing to do business with this firm instead of considering similar offerings of the competition, or the buyers are willing to pay higher prices.

In markets where many firms compete or where there are a few buyers with strong bargaining power, having an absolute advantage also means that the firm has the highest comparative advantage over all similar offerings and hence being able to neutralize competition. Consequently, the best choice in highly competitive markets is to focus on activities that yield the highest comparative advantage. Even market leaders are forced to focus and limit their offerings: they cannot offer everything to everyone. Having a dedicated focus also means that the firm can produce goods and/or services at a lower opportunity cost than other firms. For example, Firm A has an absolute advantage in corn seed as well as sunflower seed harvesting, but Firm B can still have a market share. If Firm B has a comparative advantage in corn seed harvesting, but a comparative disadvantage in sunflower seed harvesting, then Firm B is better off focusing its resources on corn seed production.

\subsection{Dynamic Comparative Advantage and Absorptive Capacity}

Comparative advantage is not a static concept. Trade through tougher competition expels less efficient forms from the market, reallocating market shares across the most productive firms. By concentrating production in the most efficient firms, this mechanism increases an industry's average productivity [8]. Just as a country's comparative advantage can be affected by changes in the demand and/or price of the products that it exports and imports, so can the comparative advantage of a firm. In addition, there is a growing evidence that improvements in the technological and knowledge base of a firm, and in particular its capacity to innovate can improve comparative advantage - and ultimately long term competitiveness - because it leads to improvements in productivity through more efficient use of labor, land and capital [9].

Following this logic, the comparative advantage of a firm will also change over time and be eroded unless the firm invests in knowledge capacity and innovation. Several researchers including Burgelman[10,11] and Szabo[12] have pointed out that the growth potential of medium and large corporations is limited, even with maximal exploitation of their existing competences and resources. Their ability to acquire new competences is a decisive factor in long-term success [13].

Following Vernon's theory (in [14]), highly productive firms tend to introduce either new products that boost demand from high-income buyers, or industrial processes that favor labor-saving type technology. In the early stages of the product cycle, production is characterized by highly differentiated processes so that location and the availability of specialized (i.e., highly skilled) labor is important. Later on, as the demand for the product expands, product standardization becomes possible and eventually enables the inventor firm to outsource certain parts of production to other firms, mainly abroad. In the final stages of the cycle, because of the factor price differentials, new firms with a plentiful labor supply may carry out the entire production process for the innovating firm.

When a firm aims to maintain its strategic position (comparative advantage), this often implies the purposeful rejuvenation of the scope of firm activity. The key driving force, however, is complementarities with existing activities, and this is what makes a new opportunity strategically valuable. It is widely recognized today that firms may create comparative advantages through purposeful investments in new technologies and innovations.

The task of managers in existing firms is to build a platform of capabilities culled from the resources, experiences and innovations of units, and then to upgrade and renew them systematically ahead of the competition. They need to provide answers to the following questions:

1. How will the firm's current capabilities provide a comparative advantage in the future?

2. How will a new capability enable the firm to enhance its future competitive position?

The success of innovation greatly depends on the firm's capacity to absorb and adopt external knowledge. Its absorptive capacity is the ability of a firm to recognize the value of new, external information, assimilate it, and apply it for commercial ends, and is critical for its innovative capabilities [15].

The strategic decisions made early in a firm's history generally affect its strategy for years afterward [16,17]. Romanelli[18] found that strategies tended to remain fairly constant once the firm was three years old or more. Not only do such decisions lock a firm into a strategy, but the structures and processes become part of an integrated whole over the years. It is difficult to change one element without unraveling the whole [19] (Eisenhardt, 1988). Fauchart and Keilbach[20] showed that routines create an "exploitation trap": as more routines are introduced, an organization becomes less capable of adapting to changing requirements and rejuvenating itself.

A recent survey by Boston Consulting Group[21], of 120 companies around the world in 10 major industry sectors, shows that executives are well aware of the need to match their strategy-making processes to the specific demands of their competitive environments. The survey found, however, that many of them rely on approaches that are better suited to predictable, stable environments, even when their firm environments are known to be highly volatile (in [22]). The results enforce the argument of Szabo[23] and others that managers tend to view problems in the light of their past experiences. This may be because solutions are developed by reflecting on the past. Repeated use of past memories can lead to overgeneralization bias, which in turn leads individuals to overemphasize similarities and underemphasize differences between the past and the present [24]. The innovation effort will therefore eventually fail. 
Zahra and George [25] further developed the concept by distinguishing between potential and realized absorptive capacities. The potential absorptive capacity is the ability to acquire and assimilate external knowledge. High potential absorptive capacity requires the simultaneous presence of two capabilities. First, the firm must be able to access and acquire externally-generated knowledge that is critical to its operations. Second, its routines and processes must allow the firm to analyze, process, interpret and understand the information obtained from external sources.

Realized absorptive capacity is a function of transformation and exploitation capabilities. Again, it consists of two capabilities. First, the transformation capability allows the firm to combine its existing knowledge and newly-acquired assimilated knowledge to develop and refine its routines. Second, the exploitation capability of a firm is basically its capacity to apply newly-acquired knowledge to its products or services to generate financial benefit.

Empirical work has shown that some firms have more absorptive capacity than others [26] because it requires a wide range of complementary activities, including organizational changes, firm-level training, testing, marketing and design.

\section{Methodology}

Author have chosen to use theoretical sampling to collect and analyze qualitative data to understand the idea of comparative advantage at firm level. The focus has therefore been on developing theories from a continuous comparative analysis of the data. The main advantage of theoretical sampling is that it strengthens the rigor of the study as it assures representativeness in each of the examined categories and relationships.

The sample contains firms which are leaders in their domestic industry segments. The pre-selection of the companies was based on above industry average financial performance. The EMIS database had been the prime source of financial information. The EMIS database provides a detailed and comprehensive information on companies, industries and countries. It is also known as a highly accurate and reliable data source as it is licensed from the world's top-end macroeconomic experts, industry research firms and the most authoritative statistical data providers. The database provides information for over 1.4 million companies. Out of the database, Hungarian companies were screened on the basis of their Return-On-Sales (ROS) and Return-On-Assets (ROA) indicators. ROS is widely used to evaluate a company's operational efficiency. An increasing ROS indicates that the company in question is growing to be more efficient, while a decreasing ROS could signal looming financial troubles. In contrast, ROA indicates how effective a company was at leveraging its assets to generate profit. The industry norm of this ratio may be very different across industries partly because the amount of assets tied up by the business depends on the industry itself. A manufacturing company may have a lot of capital tied up in plants and equipment, while a service firm may have a very few assets. Nevertheless, ROA provides a big picture view the overall return of the company studied especially if it is compared to industry norms. For example, a ROA that is higher than the industry norm may suggest that the company is not renewing its assets for the future. Perhaps it's not investing in new machinery and equipment, which is likely to damage its long-term prospects.

Both indicators are best used to conduct a trend analysis and compare performance over time. In order to be included in the study, the companies needed to demonstrate a higher than industry average on both indicators between 2008 and 2013.

Once the top performer companies were identified and selected, they had been approached to participate in the study. On the basis of their interest, their availability, and proximity a total of 25 corporations were studied closely between March and May 2015. All companies were private companies. Data were collected via face-to-face interviews with practitioners: managers and knowledge workers at different hierarchical levels within organizations, to take into account multiple views and interests. All together more than 100 interviews were carried out.

\section{Results and Discussion}

All the successful firms followed similar growth paths. Each of them was internationally active and there was a linearity in their growth. They all started to grow with the help of a large international organization, with which they had started to work as a supplier or distributor. Initially, the outsourcing company had absolute advantage on every activity. It usually, however, focused on high value-added activities because those resulted in the highest comparative advantages.

At the same time, the management of the supplier firms purposefully invested in technology and technological knowledge, to eliminate the their respective absolute disadvantage in comparison to the outsourcing company, as well as to create an absolute advantage over other competitors. They all confirmed that this had been deliberate: they engaged in learning with the aim of achieving more costumers and higher financial returns.

The firms which managed to diversify and become vendors for other international firms grew from one-product companies into ones producing two or more products. Those that invested in the wrong knowledge were unable to make this step and remained one-product companies (see Figure $1)$. 


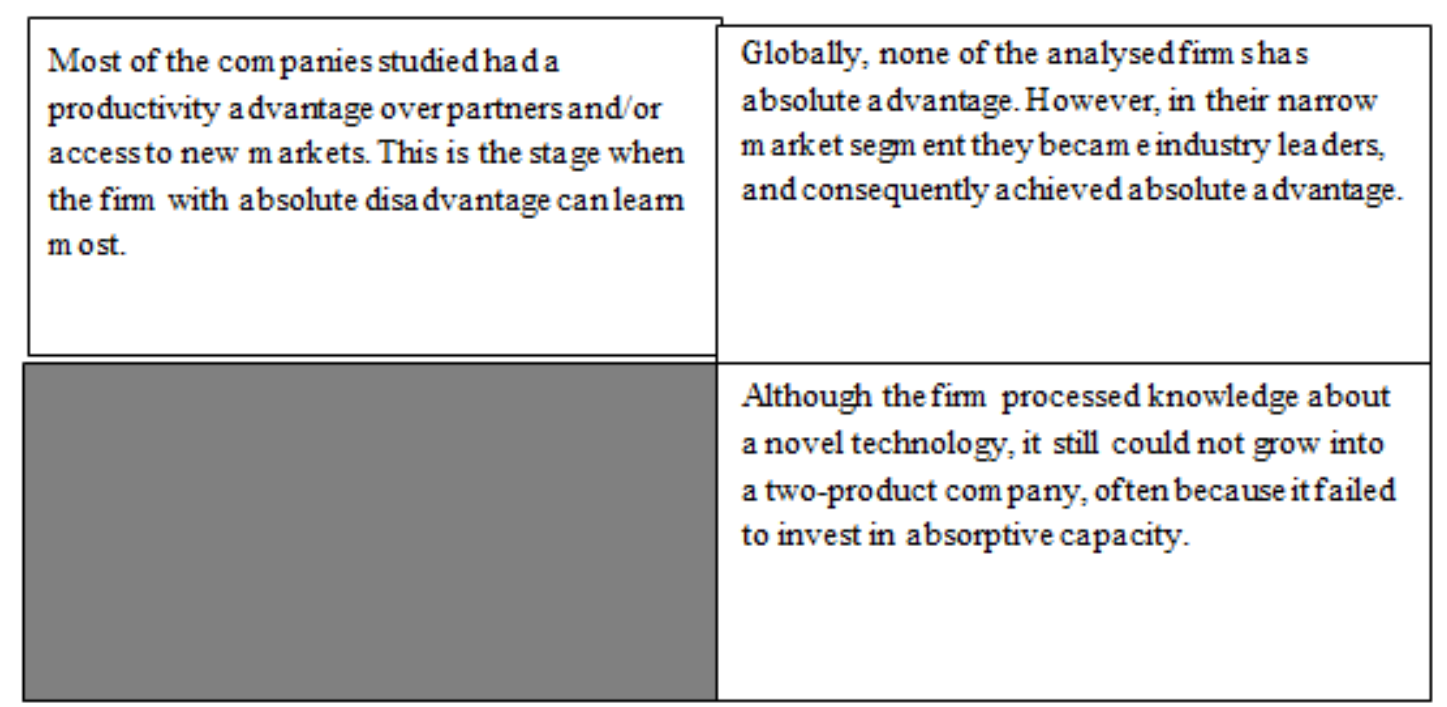

Figure 1. The advantage matrix

This study confirms that firms that encourage the search for new ideas and consciously drive learning from external sources, by establishing processes to 'learn', are far better at innovation, and have a better comparative advantage-based competitive position (see Figure 2).

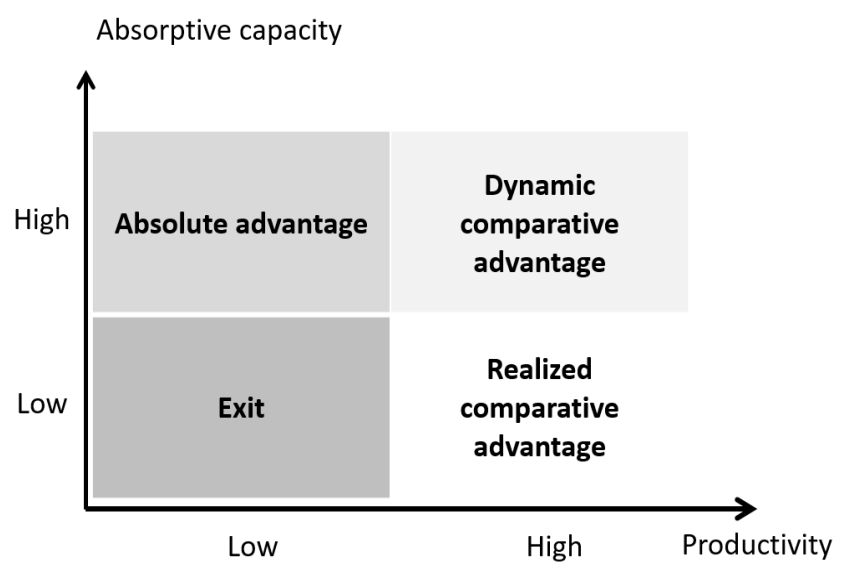

Figure 2. The relationship between absorptive capacity and productivity

Absolute advantage exists when a firm has a high absorptive capacity, both access to external knowledge and capability to transform and exploit that knowledge, but its productivity is low. That is because the firm operates in either a protected market (i.e. a monopoly) or it has introduced a break-through innovation and competition does not yet exist. Since the absolute advantage means that the firm must have sunk costs, either from protecting its market, or the effort of bringing the cutting-edge innovation to market, self-selection plays an important role. The management of such firms deliberately chooses to stay in the protected market. There is a high chance that the firm is going to fail if the protection expires or the barriers to entry disappear.

When its productivity is low and the firm has no absorptive capacity, then in a competitive situation, the firm must exit. In real life, however, it is unrealistic to think only of classical markets. Big businesses may have the power to set their own terms in the marketplace, and create wants. The individual preferences of buyers may therefore reflect the preferences of entrenched corporations. This was called the "dependence effect" by Galbraith[27]. Corporations could therefore exist without being either productive or able to innovate, but the examination of such a context is beyond the scope of this study.

There are two other options in the matrix: dynamic and realized comparative advantage. The latter is when the firm is highly productive but has low absorptive capacity. This is due to strong 'past' orientation, when management is confident that industry trends will follow previous patterns. The management thinks in terms of the "here and now" and emphasizes the repeated use of past solutions. At the moment, the firm does possess comparative advantages, which give it a competitive position. Its weak future orientation, however, means that the firm is also weak in absorptive capacity. It is either not able to access external knowledge or its internal processes and routines do not allow the integration or transformation of such external knowledge. This may result in future erosion of comparative advantage or the specialization may lead to a dead-end as the industry life-cycle declines.

Dynamic comparative advantage requires a strong future orientation. Future focus is associated with thinking about what the future holds and envisaging future events even though it is difficult to evaluate the viability or accuracy of the vision. The organization is proactive in searching for novel knowledge outside itself, including purposeful screening of the external environment. Information collected is continuously discussed and interpreted by organizational members. This is a conscious activity, and hence processes are purposefully developed for the assimilation and transformation of new knowledge in combination with existing organizational knowledge. 
Table 1. Hanges over time in comparative and absolute advantages among the companies in this study

\begin{tabular}{|c|c|c|}
\hline Industry & 5 years ago & Today \\
\hline Seed processing for propagation & Realized comparative advantage & Dynamic comparative advantage \\
\hline Vehicle and parts wholesaler & Absolute advantage & Dynamic comparative advantage \\
\hline $\begin{array}{c}\text { Electric power generation, transmission, } \\
\text { distribution }\end{array}$ & Absolute advantage & Dynamic comparative advantage \\
\hline Cutlery and tool manufacturing & Absolute advantage & Absolute advantage \\
\hline $\begin{array}{l}\text { Production of pharmaceuticals and medical } \\
\text { products }\end{array}$ & Dynamic comparative advantage & Dynamic comparative advantage \\
\hline Metallurgy & Absolute advantage & Absolute advantage \\
\hline Tourism, transport and logistics activities & Dynamic comparative advantage & Dynamic comparative advantage \\
\hline Medicines and other medical products wholesale & Dynamic comparative advantage & Dynamic comparative advantage \\
\hline Computer systems design and related services & Dynamic comparative advantage & Dynamic comparative advantage \\
\hline Retail and e-commerce & Dynamic comparative advantage & Dynamic comparative advantage \\
\hline Confectionery product manufacturing & Absolute advantage & Dynamic comparative advantage \\
\hline Bakery & Realized comparative advantage & $\begin{array}{c}\text { Exit (current situation), dynamic comparative } \\
\text { advantage (targeted) }\end{array}$ \\
\hline Architectural and structural metals manufacturing & Realized comparative advantage & $\begin{array}{c}\text { Exit (current situation), dynamic comparative } \\
\text { advantage (targeted) }\end{array}$ \\
\hline Railway transportation & Absolute advantage & Dynamic comparative advantage \\
\hline Management consulting & Exit & Dynamic comparative advantage \\
\hline Health care center & Absolute advantage & Absolute advantage \\
\hline Software developer & Absolute advantage & Dynamic comparative advantage \\
\hline Electronic products wholesale & Absolute advantage & Absolute advantage \\
\hline $\begin{array}{l}\text { Insurance brokers, intermediaries and related } \\
\text { activities }\end{array}$ & Absolute advantage & Absolute advantage \\
\hline Iron, steel and other metallurgy & Realized comparative advantage & Realized comparative advantage \\
\hline Communications equipment manufacturing & Absolute advantage & Absolute advantage \\
\hline Production of basic chemicals & Absolute advantage & Absolute advantage \\
\hline Cement and concrete & Absolute advantage & Dynamic comparative advantage \\
\hline Manufacture of railway vehicles and vehicle parts & Dynamic comparative advantage & Dynamic comparative advantage \\
\hline Transportation & Absolute advantage & Dynamic comparative advantage \\
\hline
\end{tabular}

Out of the 25 cases, 17 realized that dynamic comparative advantage was the right way to gain or maintain competitive advantage (see Table 1). In seven cases, the absolute advantage was stable and they did not want to change, and in one case the realized comparative advantage still enables the firm to achieve profits.

The world has changed a great deal in the past five years, and 11 companies reached or defended their segment leader position by increasing productivity or absorptive capacity. They are now able to benefit from dynamic comparative advantages. In industries harmed by the global crisis or disrupted by another linked industry, realized comparative advantages turned to be a dead-end, as shown by two cases in the sample. These firms invested in improving their productivity, but could not exploit this investment, as the markets got more volatile and more resilience was needed.

\section{Conclusions}

This paper examined how to gain and maintain sustainable competitive advantage. It analyzed 25 companies that were market leaders in their segment, using qualitative research techniques and a multi-level approach. The results suggest that both absolute and comparative advantages can lead to competitive advantage, but only dynamic comparative advantage leads to sustainable competitive advantage.

An important result of this research is that comparative advantage is dynamic in nature. Organizations are forced to focus and limit their offerings on goods and services that are produced at lower opportunity cost than other firms because Comparative advantage is not remaining static over the years. Trade through tougher competition expels less efficient forms from the market. On the other hand, that creates a Schumpeterian opportunity to grow for those who realize the importance improving comparative advantage of the firm.

In case of dynamic environment and highly competitive markets, that firm can achieve sustainable competitiveness whose management deliberately focuses on activities in which its comparative advantage can be improved. This finding is in contrast with the logic of core competence, as it suggests that investment into high productivity and high 
absorptive capacity is the way to improve comparative advantage in the long-run, and as such, it can ensure future competitiveness. That is why managers must have future orientation and curiosity to attain the proper level of potential absorptive capacity.

Finally, the study also confirms that firms that consciously drive learning from external sources, are far better at innovation, and have a better comparative advantage-based competitive position. By establishing purposefully routines and processes that enable the assimilation and transformation of knowledge, managers create organizational competences that address opportunities arising in the rapidly changing environments.

\section{REFERENCES}

[1] R.G. McGrath, Transient Advantage, Harvard Business Review, 2013 June, 64-70.

[2] Ricardo, David. Principles of political economy and taxation. G. Bell and sons, 1891.

[3] M.J. Melitz, The impact of trade on intra-industry reallocations and aggregate industry productivity, Econometrica, 2003, 71, 1695-1725.

[4] E. Helpman, J. Melitz, S. R. Yeaple, Export versus FDI with heterogeneous firms, American Economic Review, 94, 300-316.

[5] D. Greenaway, R. Kneller, Firm heterogeneity, exporting and foreign direct investment, The Economic Journal, 117(517), 134-161.

[6] S Johansson, R\&D accessibility and comparative advantages in quality differentiated goods, IFCAI Journal of Knowledge Management, 4, 29-50.

[7] J.Y. Lee, S. Sridhar, C. M. Henderson, R. W. Palmatier, Effect of customer-centric structure on long-term financial performance, Marketing Science, 34(2), 250-268.

[8] A. B. Bernard, S. J. Redding, P. K. Schott, Comparative advantage and heterogeneous firms, Review of Economic Studies, 74 (1), 31-66.

[9] L. Soete, Regions and innovation policies: the way forward, In Regions and Innovation Policy, OECD Review of Regional Innovation, OECD Publishing, 2011.

[10] R. A. Burgelman, A model of the interaction of strategic behavior, corporate context, and the concept of strategy, Academy of Management Review, 8, 61-70.

[11] R. A. Burgelman, Designs for corporate entrepreneurship in

${ }^{\mathrm{i}}$ Lilla Hortovanyi gratefully acknowledges support from Bolyai Janos Research Grant established firms, California Management Review, 26, 154-166.

[12] Z. R. Szabo, Adaptációs stratégiák a kialakuló bioetanol-iparágban, Vezetéstudomány, 11, 54-63.

[13] A. Ferincz, Entrepreneur-Manager Discrepancy as an inhibitor of ambidexterity, Conference paper. EURAM 2016 Conference, Paris.

[14] T. C. Lowinger, The technology factor and export performance of U.S. manufacturing industries," Economic Inquiry, 13, 221-236.

[15] W. M. Cohen, D. A. Levinthal, Absorptive capacity: a new perspective on learning and innovation, Administrative Science Quarterly, 35, 128-152.

[16] W. R. Sandberg, Strategic management's potential contribution to a Theory of Entrepreneurship, Entrepreneurship Theory and Practice, 16, 73-90.

[17] Z. R. Szabo, Adaptáció és a növekedés lehetőségei és korlátai a kkv-szektorban, In Z. R. Szabó (Ed.) Innováció vezetői szemmel. Egy könyv azoknak a vezetőknek, akik a jövőt formálják, Aula, Budapest, 2012, 35-51.

[18] E. Romanelli, Environments and strategies of organization start-up: Effects on early survival, Administrative Science Quarterly, 34, 369-387.

[19] K. M. Eisenhardt, Agency- and institutional-theory explanations: the case of retail sales compensation, The Academy of Management Journal, 31, 488-511.

[20] E. Fauchart, M. Keilbach, Testing a model of exploration and exploitation as innovation strategies, Small Business Economics, 33, 257-272.

[21] Boston Consulting Group, Capitalizing on recovery, 2013, online available from: http://www.bcg.de/documents/file139 325.pdf

[22] M. Reeves, C. Love, P. Tillmanns, Your strategy needs a strategy, Harvard Business Review, 90(9), 2-9.

[23] Z. R. Szabo, Strategic adaptation, ambidexterity and competitiveness, Lambert Academic Publishing, USA

[24] A. C. Bluedorn, 2002, The human organization of time: Temporal realities and experience, Stanford, CA: Stanford University Press.

[25] S. A. Zahra, G. George, Absorptive capacity: a review, reconceptualization, and extension, Academy of Management Review, 27, 185-203.

[26] R. Harris, Q. C. Li, Exporting, R\&D, and absorptive capacity in UK establishments, Oxford Economic Papers, 61, 74-103.

[27] J.K. Galbraith, 1952, The Affluent Society. Boston: Houghton Mifflin. 